\title{
Financial Advice and Portfolio Diversification
}

\author{
Augustine C. Arize ${ }^{1}$, Tao $\mathrm{Guo}^{2}$, John Malindretos ${ }^{2}$, Ikechukwu Ndu ${ }^{3} \&$ Lawrence Verzani $^{2}$ \\ ${ }^{1}$ Department of Economics and Finance, College of Business, Texas A\&M, Commerce \\ ${ }^{2}$ Department of Economics, Finance and Global Business, Cotsakos College of Business, William Paterson University \\ ${ }^{3}$ Department of Management, School of Business, Economics and Informatics, Birkbeck, University of London \\ Correspondence: John Malindretos, Department of Economics, Finance and Global Business, Cotsakos College of \\ Business, William Paterson University, USA. E-mail: jnmalindre@optonline.net
}

Received: April 22, 2019

Accepted: October 27, 2019

Online Published: November 5, 2019

doi:10.5430/afr.v8n4p178

URL: https://doi.org/10.5430/afr.v8n4p178

\begin{abstract}
This paper examines whether households diversify their investment portfolios and whether portfolio diversification could be affected by where investors seek advice. We found that respondents find advice from banks, insurance companies, and brokerage houses less helpful compared to reading investment research and financial periodicals when making their portfolio decisions. Comparing among the advice from all types of financial institutions or financial professionals, it is found that advice from brokerage houses is still the most helpful. But when looking at their actual portfolio diversification, those who rely on brokers' advice ended up with a less diversified portfolio. These findings support our hypothesis that investors' portfolio could be negatively influenced because of the services they received from brokerage houses.
\end{abstract}

Keywords: brokerage houses, diversification, financial advisors, investment advice, portfolios

\section{Introduction}

This paper examines the normative suggestion, within the investment literature, that households diversify their investment portfolios and whether portfolio diversification could be affected by where investors seek advice. Failure for households to diversify their investment portfolios means they will be subjected to significantly more unsystematic risk for which they are not compensated. In a study of Swedish households, Calvet et. al. (2007) estimated the loss of under-diversified households as being more the 5\% of accumulated wealth per year. Five hundred basis points is a substantial drain on a portfolio. Consider a household that invests $\$ 12,000$ a year for 30 years that $5 \%$ drain equates to about $\$ 840,000$ less at retirement.

Recognizing the households that are more likely to avoid investment mistakes, like failing to diversify their portfolio, may allow the creation of public policy or business practices to steer more households in the right direction. Better results from retirement planning can mean fewer households needing to rely on social welfare programs. Fewer households relying on social welfare programs is in the public interest. Investment advisory services, publicly available investment research and investment media can all influence household investor behavior. Knowing which of these sources are associated with the best outcomes for household investors and promoting those sources could improve household investor outcomes. In addition, studying investment mistakes and the associations households that make those mistakes have can help industry demonstrate value and best serve their clients.

\section{Literature Review}

Markowitz (1952) suggests that investing in large number of varying stocks reduces portfolio risk while maintaining investment return, which is referred to as the benefit of portfolio diversification. However, literature finds that many investors don't hold diversified portfolio as proposed by the theory. For example, Blume, and Friend (1975) find that about half the households in their study hold a majority of their investments in only one stock.

The first study to point out the discrepancy between normative suggestions regarding diversification and investor behavior was Blume, and Friend (1975) which finds that the roughly half the households in their data set hold at least 63 percent of their stock portfolio in one holding. Kramer (2012) using a large data set of Dutch investors finds that advised investors are better diversified. Studying a data set from a large German retail bank Bluethgen et al. (2008) also find a positive relationship between advised investors and diversification. Bhattacharya et al. (2012) using data from a German brokerage do not find evidence that advice improves measures of investor diversification. Kawano (2010) 
using data from the Survey of Consumer Finance (SCF) reports a positive relationship between the number of stocks owned and receiving investment advice from a broker but does not find evidence that seeking investment advice from a financial planner is significant. Kawano did not however try to test based on a minimum level of diversification. Curcuru et al. (2004) establish a test for minimum standard of diversification using the SCF but does not look at the relationship between financial advice and diversification. Based on the conflicting results the subject of financial advice and investor portfolio diversification warrants further attention. There is also more need of research utilizing a nationally representative sample of U.S. households.

Empirical evidence suggests that households fail to incorporate MPT as there is substantial documentation of underdiversification among households in the literature (Kelly 1995, Curcuru et al. 2004, Home et al. 1975, Polkovnichenko 2005, Campbell 2006). Campbell (2006) highlights this and other disconnects from empirical and normative research as common investment mistakes made by households.

Interestingly there is evidence that the most risk averse households have some of the greatest levels of underdiversification. Lai and Xiao (2010) explain that risk averse households are more likely to have high concentrations of employer stock in their portfolio. Many times employer stock may be the only exposure to equity holdings these households have. This type of underdiversification is particularly bad because their income is then correlated with their equity holdings such that if the company they work for goes out of business they can lose both thereby putting them at substantial risk. They attribute this to mere-exposure effect, the phenomenon whereby people tend to have preferences for whatever they have more familiarity with or repeated exposure. This is similar in nature to the home bias effect which is the tendency for investors to invest in stocks from the country of origin as evidenced by French and Poterba (1991). Also similar is the company stock effect proposed by Benartzi and Thaler (2001) which finds consumers underestimate the risk of their employer's stock. This is just one aspect of undiversification but it highlights the serious nature of the problem. There is plenty of evidence regarding the divergence of household behavior and prescriptive economic suggestions. For example Haliassos and Bertaut (1995) find a lack of equity participation by U.S. households despite the fact that expected utility models predict that most rational households should have at least some exposure to equities. As already mentioned we see pervasive underdiversification among households despite normative suggestions to the contrary. Campbell (2006) attributes the disparity between empirical evidence and normative prescriptions to investment mistakes made by households. Campbell suggests financial sophistication is a chief component of these mistakes as age, income, and education are often found to be statistically significant factors in many of the investment mistakes studied in the literature. More direct measures of financial sophistication exist in studies such as Graham, Harvey, and Huang (2005) who find that investors who self-report higher levels of financial sophistication have more internationally diversified holdings.

There are substantial costs in acquiring the knowledge to make optimal investment decisions. This can be done through formal education or self-study including investment periodicals and published investment research. However, without a sufficient background in investments determining credible sources of information may be difficult. Instead of acquiring the necessary knowledge oneself in order to make better investment decisions one can rely on professionals. Stigler (1961) holds that information collected by a central intermediary, like a financial services professional, can be more efficient as the cost of acquiring that information can be shared among any number of households. Households that lacking investment savvy may turn to financial advice to help avoid costly investment mistakes.

Theoretically households maybe able to achieve better investment results and avoid costly mistakes like not diversifying their portfolio by seeking professional investment advice at a cost that is lower than they may be able to achieve on their own. However, the downside to professional advice are agency costs as pointed out by Eisenhardt (1989). Agency costs exist because the interests of financial service professionals and their clients are not perfectly aligned. When financial service professionals have incentives for behavior that are not in their clients interest the resultant agency costs can outweigh the benefits of scale economies described by Stigler (1961).

There is evidence that financial advice affects investor behavior. Studies confirm the positive relationship between financial advice and stock market participation (Jansen et al. 2008, Bluethgen et al. 2008, Guiso and Jappelli 2005). If we consider lack of stock market participation as an investment mistake as suggested by Campbell (2006) then perhaps households who seek professional financial advice will be associated with fewer investment problems overall, including lack of diversification. In fairness though, many financial advisors have an economic incentive to encourage equity market participation. The same cannot be said for encouraging households to diversify their positions. Although financial advisors can be rewarded with business retention and referrals for giving good advice,

it is likely difficult for households to evaluate what good advice is without the necessary investment in specific 
knowledge related to personal finance. Additionally, there are examples where financial advice has been associated with poor financial choices (Mullainathan et al. 2012, Chalmers and Reteur 2012) or where advice was not found to be significant in influencing investor behavior (Bhattacharya et al. 2011).

\section{Research Hypothesis}

Traditional finance theory assumes that investors are fully rational, have access to full information and the market and there is no market friction. Behavioral finance theory challenges the assumptions and suggests that investors usually display bounded rationality. Due to limited access to information and limited cognitive ability, their decision could deviate from being optimal, which could explain the under-diversification in their portfolio. Human capital theory suggests that, many investors will be better off using financial service professional to make an optimal decision. The agency theory suggests that there might exists a conflict of interest between principal (individual investors) and their agents (the professionals they hire). So, investors' portfolio decision can be negatively influenced by the professionals they work with as found in several studies (Mullainathan et al. 2012, Chalmers and Reteur 2012), which could also explain the under-diversification in investors' portfolio. Commissions can drive agency costs and therefore financial service professionals who have a commission based compensation structure may have worse outcomes than financial professionals who are compensated solely for their advice, like an accountant. We therefore test the following hypothesis:

\section{H1: Investors who work with broker house for their financial advice are less likely to have a diversified portfolio.}

\section{Methodology and Data}

This study uses a unique dataset collected from individual investors working with a stock brokerage firm. Investors were asked to complete a paper questionnaire voluntarily and autonomously after a client meeting. The survey is particularly useful to our research question because it includes information about family investment patterns, investment approaches, beliefs, and investor demographics.

A measure of household portfolio diversification is developed based on investor self-reported mutual fund and stock ownership. The survey asks the number of mutual funds and stock holdings. A household is defined to have a diversified portfolio if it invests in more than 3 mutual funds or invests in more than 15 stock companies. Table 1 presents the summary statistics of the diversification measure and key demographic control variables. About $69 \%$ of respondents in this survey had a diversified investment portfolio. About $91 \%$ of the respondents were male, consistent with the evidence that males are the primary financial decision makers in the family. More than half of respondents were aged 65 years old or above, suggesting an even more important reason for a diversified portfolio. About $38 \%$ of respondents were aged between 45 to 64, a group that is in need for an appropriate investment portfolio for wealth accumulation. About $94 \%$ of respondents were White. $83 \%$ of respondents were married which is consistent with their age distribution. About $73 \%$ of respondents had a college degree or higher, suggesting that this is a more educated group related to the general public. About $41 \%$ of respondents had household income between $\$ 50,000$ to $\$ 100,000$ and another $25 \%$ of respondent had household income over $\$ 100,000$, consistent with the prior evidence that this is a group that needs to make investment decisions. About $48 \%$ of respondents also reported to rely on a financial professional for financial advice. 
Table 1. Summary Statistics of Key Variables

\begin{tabular}{ll}
\hline Variable Name & Frequency (N=128) \\
\hline Have a Diversified Portfolio & $68.75 \%$ \\
Not Have a Diversified Portfolio & $31.25 \%$ \\
Gender & \\
Male & $91.20 \%$ \\
Female & $8.80 \%$ \\
Age & \\
26 to 44 & $10.16 \%$ \\
45 to 64 & $38.28 \%$ \\
65 and Above & $51.56 \%$ \\
White & $93.75 \%$ \\
Non-white & $6.25 \%$ \\
Married & $82.79 \%$ \\
Unmarried & $17.21 \%$ \\
Highest Education & \\
High School or Lower & $26.56 \%$ \\
College Degree & $40.63 \%$ \\
Master Above and Professional Degree & $32.81 \%$ \\
Household Income & \\
Less than $\$ 50,000$ & $34.43 \%$ \\
\$50,000- \$100,000 & $40.98 \%$ \\
Above \$100,000 & $24.59 \%$ \\
Rely on Financial Professional & $48.44 \%$ \\
Not Rely on Financial Professional & $51.56 \%$ \\
\hline
\end{tabular}

\section{Research Findings}

Table 2 presents the summary statistics of how helpful respondents find receiving financial advice from various resources. Looking at the full sample, respondents tended to find financial advice from reading investment research and periodicals more helpful than advice from any type of financial professionals. On a scale of one to four with four as the more useful, both reading investment research and reading periodicals had an average helpfulness of 2.90 and

2.66 respectively. Comparing helpfulness of advice from different financial professionals, it is found that financial advice from brokerage houses was more helpful than financial advice from a bank, insurance company or other professionals. A sub-group analysis was conducted to investigate whether respondents with a diversified portfolio had a different perception of helpfulness compared to their counterparts. Consistent with prior findings, it is observed that both groups found investment research and periodicals more helpful than advices from banks, insurance companies, brokerage houses or other professionals. Advice from brokerage houses was still viewed more helpful than advice from bank, insurance company or other financial professionals. Those with a diversified investment portfolio found advice from investment research and periodicals much more helpful, and advice from various financial professionals much less helpful. This suggests that respondents with a diversified investment portfolio were more likely to be more financial sophisticated and make financial decision on their own. 
Table 2. Helpfulness of Financial Advice from Different Sources

\begin{tabular}{|c|c|c|c|c|}
\hline \multirow[t]{2}{*}{ Helpfulness of Financial Advice from } & \multirow[t]{2}{*}{$\mathrm{N}$} & \multirow[t]{2}{*}{ Full Sample } & \multicolumn{2}{|c|}{ Diversified Portfolio } \\
\hline & & & No & Yes \\
\hline Banks & 110 & 1.22 & 1.53 & 1.09 \\
\hline Insurance Companies & 108 & 1.20 & 1.26 & 1.18 \\
\hline Brokerage Houses & 116 & 2.02 & 2.06 & 2.00 \\
\hline Other Professionals & 106 & 1.91 & 1.94 & 1.89 \\
\hline Read Investment Research & 118 & 2.90 & 2.58 & 3.04 \\
\hline Read Investment Periodicals & 117 & 2.66 & 2.38 & 2.76 \\
\hline
\end{tabular}

We then investigate how the advice from brokerage houses affects respondents' diversification decision. Table 3 presents the logistic regression results estimated through a set of hierarchical model. The dependent variable is the diversification measure created in this study. Besides key demographic control variables, the hierarchical model includes one after another, whether respondents reply on financial professional for an advice, whether respondents found advice from brokerage houses helpful and the interaction of the prior two variables. The full model investigates whether respondents have a diversified portfolio if they rely on a financial professional and find advice from brokerage house more helpful. Odds ratios were reported in table 3. A odds ratio larger than 1 suggests that an event is more likely to happen, while a odds ratio smaller than 1 suggests that an event is less likely to happen. Look at the model 3, it is observed that the odds ratio for the interaction term of whether respondents rely on financial professionals for advice and whether respondents found advice from brokerage houses helpful is 0.041 and statistically significant at the $1 \%$ level. This suggests that those who rely on financial professionals and find advice from brokerage houses more helpful were significantly less likely to have a diversified portfolio. This provides supporting evidence to our hypothesis that respondents might experience negative financial consequence when working with a brokerage house while they also viewed their advice more helpful than advice from other financial professionals. The actual quality of advice was not consistent with how it was perceived. What is more, it is observed that education and income had a positive relation with whether respondents have a diversified portfolio. Those who had no college degree were significantly less like to have a diversified portfolio than those with a college degree. Those with less than $\$ 50,000$ household income were significantly less likely to have a diversified portfolio than those with a household income over $\$ 100,000$. 
Table 3. The Impact of Financial Advice on Household Portfolio Diversification, Odds Ratio Estimated through Logistic Regression

\begin{tabular}{llll}
\hline Variables & Model 1 & Model 2 & Model 3 \\
\hline Male & 2.843 & 2.562 & 4.475 \\
\hline Age $<45$ vs Age $>65$ & 1.176 & 1.233 & 1.013 \\
Age 45 to 65 vs Age $>65$ & 1.157 & 1.192 & 1.344 \\
White & 1.633 & 1.256 & 2.336 \\
Married & 0.634 & 0.598 & 0.49 \\
Less than College & 0.433 & $0.403^{*}$ & $0.468^{*}$ \\
College Degree & 0.898 & 0.902 & 1.256 \\
Income below \$50,0000 & 0.344 & $0.304^{*}$ & $0.298^{*}$ \\
Income \$50,000 to \$100,000 & 0.534 & 0.533 & 0.568 \\
Rely on Financial Professionals & 0.646 & & 1.249 \\
Find Brokerage House Helpful & & 0.691 & 6.244 \\
Interaction of above Two & & & $0.041^{* *}$ \\
\hline
\end{tabular}

*Statistically significant at the $10 \%$ level of Significance

** Statistically significant at the $1 \%$ level of significance

\section{Discussion}

This study shows that respondents find advice from banks, insurance companies, and brokerage houses less helpful compared to reading investment research and financial periodicals when making their portfolio decisions. Comparing among the advice from just the financial institutions and financial professionals, survey respondents indicated that advice from brokerage houses was more helpful than services from banks, insurance companies and other financial professionals. But when looking at their actual portfolio diversification, those who rely on brokers advice ended up with a less diversified portfolio. These findings support our hypothesis that investors' portfolio could be negatively influenced because of the services they received from brokerage houses.

There exists a gap between the perceived quality of financial advice from a stock broker and their actual quality. Due to the compensation structure, the conflict of interests are more likely to occur when a stock broker is involved. The findings from this study support this argument. Public policy needs to address the issue and protect these investors. From this extent, the fiduciary rule proposed by the department of labor would certainly benefit the investors by requiring their advisor to work on a capacity of a fiduciary when advising retirement accounts and ensuring that that commissions among various investment products used for retirement are the same. The Security Exchange Commission is also in the process of drafting their own fiduciary rule.

Financial advisory services need to be able to demonstrate their value to clients. The various investment mistakes made by households as pointed out by Campbell (2006) can all be pointed to as reasons why households should consider professional financial advice. Additionally, financial service firms need to know how to motivate their clients to follow their advice. Providing measurable results can allow these firms to demonstrate the financial harm that can be afflicted on households not investing using optimal strategies.

\section{References}

Barber, B. M. \& Odean, T. (2001). Boys Will be Boys: Gender, Overconfidence, and Common Stock Investment. The Quarterly Journal of Economics, 116(1), 261-292. https://doi.org/10.1162/003355301556400

Benartzi, S., Thaler, R.H. (2001). Naïve Diversification Strategies in Defined Contribution Saving Plans. American Economic Review, 91(1), 79-98.

Bhattacariya, Utpal, Hackethal, A., Kaesler ,S., Loos, B., Meyer, S. "Is Unbiased Financial Advice to Retail Investors Sufficient? Answers from a Large Field Study". Review of Financial Studies, 25, 975-1032.

Bilias, Y., Georgarakos, D. \& Haliassos, M. (2009). Equity Culture and the Distribution of Wealth. Available at SSRN 731805. https://doi.org/10.2139/ssrn.731805 
Bluethgen, R., Gintschel, A., Hackethal, A. \& Mueller, A. (2008). Financial Advice and Individual Investors Portfolios. Available at SSRN 968197. https://doi.org/10.2139/ssrn.968197

Blume, M. E. \& Friend, I. (1975). The Asset Structure of Individual Portfolios and Some Implications for Utility Functions. The Journal of Finance, 30(2), 585-603. https://doi.org/10.1111/j.1540-6261.1975.tb01833.x

Campbell, J. Y. (2006). Household Finance. The Journal of Finance, 61(4), 1553-1604. https://doi.org/10.1111/j.1540-6261.2006.00883.x

Chalmers, J. \& Reuter, J. (2012). What is the Impact of Financial Advisors on Retirement Portfolio Choices and Outcomes? (No. w18158). National Bureau of Economic Research. https://doi.org/10.2139/ssrn.2078536

Chang, M. (2005). With a Little Help from My Friends (and my financial planner). Social Forces, 83(4), 1469-1497. https://doi.org/10.1353/sof.2005.0061

Chong, J. \& Phillips, M. (2013). Portfolio Size Revisited. The Journal of Wealth Management, 15(4), 49-60. https://doi.org/10.3905/jwm.2013.15.4.049

Curcuru, S., Heaton, J., Lucas, D. \& Moore, D. (2004). Heterogeneity and Portfolio Choice: Theory and Evidence. Handbook of Financial Econometrics, 1.

Davidoff, T., Brown, J. \& Diamond, P. (2005). Annuities and Individual Welfare. American Economic Review, 95(5), 1573-1590. https://doi.org/10.1257/000282805775014281

French, K., \& J. M. Poterba, (1991). International Diversification and International Equity Markets. American Economic Review, 81, 222-226. https://doi.org/10.3386/w3609

Guiso, L. \& Jappelli, T. (2005). Household Portfolio Choice and Diversification Strategies. Trends in Saving and Wealth, Working Paper.

Guiso, L. \& Jappelli, T. (2008). Financial Literacy and Portfolio Diversification. Working Paper European University Institute

Graham, J. R., Harvey, C. R. \& Huang, H. (2009). Investor Competence, Trading Frequency, and Home Bias. Management Science, 55(7), 1094-1106. https://doi.org/10.1287/mnsc.1090.1009

Haliassos, M. \& Bertaut, C. C. (1995). Why do so Few Hold Stocks? The Economic Journal, 1110-1129. https://doi.org/10.2307/2235407

Huston, S. J., Finke, M. S. \& Smith, H. (2012). A Financial Sophistication Proxy for the Survey of Consumer Finances. Applied Economics Letters, 19(13), 1275-1278. https://doi.org/10.1080/13504851.2011.619485

Investment Company Institute and Securities Industry Association. (2005). Equity Ownership in America, Washington, DC: Investment Company Institute, available at: http://www. ici. org/pdf/rpt_05_equity_owners. pdf.

Jansen, C., Fishcher \& Hackethal, A. (2008). The Influence of Financial Advice on the Asset Allocation of Individual Investors. EFA 2008 Athens Meetings Paper. https://doi.org/10.2139/ssrn.1102092

Kawano, L. (2010). Does It Matter Who You Talk To? The Role of Financial Advice Sources in Portfolio Responses to Taxes, umich.edu.

Kelly, M. (1995). All their Eggs in One Basket: Portfolio Diversification of US Households. Journal of Economic Behavior and Organization, 27(1), 87-96. https://doi.org/10.1016/0167-2681(95)00006-E

Kramer, M. M. (2012). Financial Advice and Individual Investor Portfolio Performance. Financial Management, 41(2), 395-428. https://doi.org/10.1111/j.1755-053X.2012.01185.x

Lai, C. W. \& Xiao, J. J. (2010). Consumer Biases and Competences in Company Stock Holdings. Journal of Consumer Affairs, 44(1), 179-212. https://doi.org/10.1111/j.1745-6606.2010.01162.x

Lusardi, A., Mitchell, O.S. (2008). Planning and Financial Literacy: How do Women Fare? American Economic Review, 98, 413-417. https://doi.org/10.1257/aer.98.2.413

Markowitz, H. (1952). Portfolio selection. The Journal of Finance, 7(1), 77-91. https://doi.org/10.1111/j.1540-6261.1952.tb01525.x

Martin, T. \& Finke, M. (2012). Planning for Retirement, Available at https://doi.org/10.2139/ssrn.2195138

SSRN

2195138.

Moore, J. \& Mitchell, O. (1998). Projected Retirement Wealth and Savings Adequacy in the Health and Retirement 
Study, National Bureau of Economics Research Working Paper, No. w6240. https://doi.org/10.3386/w6240

Polkovnichenko, V. (2005). Household Portfolio Diversification: A Case for Rank-Dependent Preferences. Review of Financial Studies, 18(4), 1467-1502. https://doi.org/10.1093/rfs/hhi033

Samuelson, W. \& Zeckhauser, R. (1988). Status Quo Bias in Decision Making. Journal of risk and uncertainty, 1(1), 7-59. https://doi.org/10.1007/BF00055564

Shawky, H. A. \& Smith, D. M. (2005). Optimal Number of Stock Holdings in Mutual Fund Portfolios Based on Market Performance. Financial Review, 40(4), 481-495. https://doi.org/10.1111/j.1540-6288.2005.00120.x

Statman, M. (1987). How Many Stocks Make a Diversified Portfolio? Journal of Financial and Quantitative Analysis, 22, 353-363.https://doi.org/10.2307/2330969

Stigler, G. (1961). The Economics of Information. The Journal of Political Economy, 69(3), 213-225. https://doi.org/10.1086/258464

Yaari, M. (1965). Uncertain Lifetime, Life Insurance, and the Theory of the Consumer, Review of Economic Studies, 32(2), 137-150. https://doi.org/10.2307/2296058

Zajonc, Robert B. (1968). Attitudinal Effects of Mere Exposure. Journal of Personality and Social Psychology Monograph Supplement, 9, 1-27. https://doi.org/10.1037/h0025848 